\title{
Muhammadiyah Sebagai Gerakan Pendidikan
}

\section{Syamsul Huda,}

STIT Muhammadiyah Bojonegoro

Email :mbsjannati@gmail.com

Dahani Kusumawati

Universitas Bondowoso

Email : dahanikusumawati@yahoo.com

\begin{tabular}{ll}
\hline Submission & Abstract \\
Track: & $\begin{array}{l}\text { The identity of Muhammadiyah as a modern movement cannot be separated } \\
\text { from the conceptualization produced in the field of education. The colonial era } \\
\text { which is identical with the dichotomy of education and science, began to be }\end{array}$ \\
Received: & $\begin{array}{l}\text { reduced by the Muhammadiyah movement that carries scientific integration, a } \\
\text { balance between science and religion and also as the concern expression of KH. }\end{array}$ \\
Final Revision: & $\begin{array}{l}\text { Ahmad Dahlan towards education. The historicity of Muhammadiyah as an } \\
\text { educational movement can be referred to the formulations of the purpose of the } \\
\text { Muhammadiyah's presence started from 1921 until 1971 which describe }\end{array}$ \\
Available online: & $\begin{array}{l}\text { education as the basis for its movements and actions. Muhammadiyah wants to } \\
\text { provide a new perspective namely education is holistic integrative, not in a partial } \\
\text { dichotomous area, which can contribute to the development and progress of the }\end{array}$ \\
Corresponding & nation.
\end{tabular}

Name \& E-mail Address

\section{Syamsul Huda}

mbsjannati@gmail.com

\section{Dahani Kusumawati}

dahanikusumawati@yahoo.com

\section{Keywords: Muhammadiyah, education}

Abstrak

Identitas Muhammadiyah sebagai gerakan modern, tidak bisa dilepaskan atas konseptualiasasi yang dihasilkan dalam bidang pendidikan. Era kolonial yang identik dengan dikotomi pendidikan dan keilmuan, mulai tereduksi oleh gerakan Muhammadiyah yang mengusung integrasi keilmuan, penyeimbangan antara ilmu pengetahuan dan agama serta sekaligus sebagai ungkapan keprihatinan $\mathrm{KH}$. Ahmad Dahlan terhadap bidang pendidikan. Historisitas Muhammadiyah sebagai gerakan pendidikan dapat dirujuk pada rumusan-rumusan tujuan hadirnya Muhammadiyah mulai tahun 1921 hingga 1971 yang menggambarkan pendidikan sebagai dasar gerak dan langkahnya. Muhammadiyah ingin memberikan perspektif baru bahwa pendidikan bersifat integratif holistik, bukan pada area dikotomis parsial, yang dapat memberikan kontribusi terhadap perkembangan dan kemajuan bangsa.

Keywords: Muhammadiyah, pendidikan.

\section{PENDAHULUAN.}

Saat kolonial Belanda menjajah bumi nusantara, Pendidikan Islam telah tersebar luas dalam wujud "pondok pesantren”, dimana Islam diajarkan di musholla/langgar/masjid. Sistem yang digunakan seperti sistem sorogan, bandongan, dan wetonan. Sorogan adalah sistem pendidikan dimana secara perorangan menghadap kyai dengan membawa kitab, kyai membacakan dan mengartikan kemudian sang santri menirukannya. Bandongan atau Wetonan adalah sang kyai membaca, mengartikan dan menjelaskan maksud teks dari kitab tertentu namun sang santri hanya mendengarkan penjelasan dari sang kyai. (Amien, 2015).

Potret kemajemukan organisasi sosial kemasyrakatan di Indonesia, dapat dilihat dari banyaknya organisasi yang ada mulai dari 
Persatuan Islam (Persis), Nahdatul Wathan (MW), Muhammadiyah, Nahdatul Ulama (NU) dan lainnya. Merujuk pada realitas empirik, dua nama yang disebut diakhir merupakan organisasi sosial kemasyarakatan yang mempunyai track record dalam pengembangan pendidikan di Indonsia (Mafidin, 2012). Perjalanan Muhammadiyah dalam bidang pendidikan telah melintasi beberapa era dengan berbagai suka dukanya. Sejak masa penjajahan Belanda, masa pendudukan jepang, masa Orde Lama, masa Orde Baru dan masa reformasi. Sejarah membuktikan bahwa pendidikan Muhammadiyah tetap tegak dan kokoh berdiri dalam memainkan peran demi mencerdaskan bangsa. Disisi lain, tak sedikit organisasi baru yang bermunculan jauh dibelakang Muhammadiyah yang tak berjatuhan dan tidak sanggup melawan beragam halangan dan rintangan yang datang menghadang di sepanjang kehidupan.(Ali, 2016)

Penegasan sebagai civil society, Muhammadiyah dalam visinya menekankan pada fungsi melaksanakan sebagian peran-peran Negara (Abdul, Binfas, \& Ismail, 2014). Konkretnya, dalam peran dan keikutsertaannya demi memajukan bangsa, Muhammadiyah tidak hanya concern pada gerakan pendidikan semata. Namun, berbagai masalah bangsa yang kompleks juga menjadi sasaran dan lahan perjuangan. Gerbong Muhammadiyah tidak hanya hadir dalam upaya pengembangan lembaga pendidikan semata, Namun juga andil dalam memperbaiki permasalahan kesehatan dengan mendirikan berbagai usaha pelayanan kesehatan. Kiprah di bidang sosial, Muhammadiyah mendirikan berbagai panti asuhan. Demikian pula di sektor ekonomi dan politik, Muhammadiyah menunjukkan kiprah sedemikian besar, keluasan dimensi kajian terhadap gerakan ini memungkinkan tersusunnya suatu bidang kajian yang disebut dengan Muhammadiyah Studies (Jinan, 2015). Bentuk konkrit usaha dalam bidang pendidikan, KH. Ahmad Dahlan dapat dikatakan sebagai suatu "model" dari bangkitnya sebuah generasi yang merupakan titik pusat dari suatu pergerakan yang bangkit untuk menjawab tantangan-tantangan yang dihadapi Islam, yaitu berupa ketertinggalan dalam sistem pendidikan dan kejumudan paham agama Islam (Ni'mah, 2014).

\section{PEMBAHASAN}

\section{Interaksi Miliu dan Pemikiran}

Gerakan pendidikan yang disematkan pada Muhammadiyah tidak bisa dipisahkan dari kepribadian sosok KH. Ahmad Dahlan sebagai pendirinya. KH. Ahmad Dahlan terlahir pada tahun 1868 di Kauman, Yogyakarta dengan nama Muhammad Darwis. Beliau lahir dari pasangan Kyai Haji Abu Bakar seorang khatib masjid besar Kauman Siti Aminah binti Kyai Haji Ibrahim, penghulu besar Yogyakarta.(Hemlan Elhany, 2013) Sejak kecil, kecintaan dan kehausan terhadap ilmu pengetahuan telah menyatu dalam kepribadiannya. Beliau tumbuh dan berkembang dalam miliu keilmuan di tengah-tengah masyarakat yang terjajah, tertindas dan terbungkus oleh keterbelakangan. Semenjak kecil, Muhammad Darwis diasuh dan di didik sebagai layaknya putera Kyai. Dibawah bimbingan sang ayah, pendidikan dasarnya dimulai dengan belajar membaca, menulis, mengaji al-Quran, dan kitabkitab agama. Menjelang dewasa, beliaupun mulai mendalami ilmu-ilmu agama dari beberapa ulama 
besar waktu itu. Perkembangan kemampuan Muhammad Darwis diusia yang masih muda dapat dilihat dari penguasaan $\mathrm{d}$ atas berbagai disiplin ilmu khususnya ilmu keislaman.

Karateristik ketidakpuasan yang menjadi sifat anak muda, juga dialami oleh KH. Ahmad Dahlan ketika muda. Intelektualitas yang tajam dan tinggi yang dimilikinya memberikan dorongan untuk semakin menguasai, mendalami dan mempelajari ilmu-ilmu tersebut. Pengaruh nyata atas kondisi tersebut, KH. Ahamda Dahlan muda, disaat umur 15 tahun, memutuskan untuk pergi melaksanakan ibadah haji dan menetap di Mekkah. Kesempatan itu dimanfaatkannya berguru kepada para ulama untuk belajar beberapa keilmuan serta menguasai berbagai kitab (Arofah \& Jamu'in, 2015). Peristiwa ini terjadi dua kali dalam kehidupan beliau. Pada masa-masa inilah, beliau mulai berinteraksi dengan para pemikir dan pembaharu Islam diluar negeri. Kontruksi pemikiran pembaharuan KH. Ahmad Dahlan tidak bisa dilepaskan atas pengaruh tokoh-tokoh sentral gerakan pembaharuan dalam Islam era itu. Pemikiran KH, Ahmad Dahlan banyak dipengaruhi oleh ulama-ulama yang menjadi gurunya seperti Syeikh Ahmad Khatib dari Minangkabau, Kyai Nawawi dari Banten, Kyai Mas Abdullah dari Surabaya, dan Kyai Fakih dari Maskumambang. juga setelah membaca pemikiran-pemikiran para pembaru Islam seperti Ibn Taimiyah, Muhammad bin Abdil Wahhab, Jamaluddin Al-Afghani, Muhammad Abduh, dan Rasyid Ridha. Dengan modal kecerdasan dirinya serta interaksi selama bermukim di Saudi Arabia dan bacaan atas karya-karya para pembaru pemikiran Islam itu telah menanamkan benih ideide pembaruan dalam diri Kyai Dahlan. Jadi sekembalinya dari Arab Saudi, Kyai Dahlan justru membawa ide dan gerakan pembaruan, bukan malah menjadi konservatif (Suara Muhammadiyah, 2017).

\section{Keprihatinan Terhadap Pendidikan Bangsa}

Berawal dari keprihatinan terhadap keterpurukan Umat Islam sebagai pribumi akibat situasi dan kondisi global. Politik kolonial Belanda yang telah lama menjajah semakin menenggelamkan bangsa ini yang diliputi perasaan kerdil dan tak berdaya. Umat Islam mengalami kemandegan dan tidak terdapat sinar kebesaran dan kecemerlangan dalam diri mereka pada waktu. Kehidupan masyarakat yang serba susah, ekonomi tidak maju, pendidikan terbelakang dan kehidupan sosial budaya tidak membesarkan hati (Ni'mah, 2014), mendorong munculnya gagasan KH. Ahmad Dahlan untuk membangun balai pendidikan, sebagai langkah awal yang diformulasikan untuk menghadapi problematika obyektif yang sedang dihadapi.

Pendidikan menjadi barang mahal dan langka yang hanya bisa dinikmati oleh kalangan bangsawan. Disaat yang bersamaan, kesenjangan sosial ekonomi sedemikian menganga dan menciptakan perbedaan strata yang sangat tidak seimbang. Semua ketidakberdayaan ini pada akhirnya menjadi justification bagi lahirnya anggapan bahwa pendidikan bukan merupakan kebutuhan hidup. Bagaimana tidak, jika kebutuhan dasar pokok yang berupa sandang, pangan dan papan saja sulit terpenuhi, bagaimana mungkin seseorang bisa berfikir tentang pendidikan.

Berbeda dengan umumnya tokoh nasional di zamannya yang lebih perhatian pada ranah politik 
dan ekonomi, KH. Ahmad Dahlan mengabdikan diri sepenuhnya dalam bidang pendidikan walaupun tidak menutup kemungkinan bidangbidang lain juga mendapat perhatiannya (Ni'mah, 2014). Berbekal ilmu agama yang ia kuasai dan ide-ide para pembaharu dari Timur Tengah, Beliau bergerak untuk memperbaharui pemahaman keislaman dan pendidikan masyarakat. Melihat fenomena rendahnya minat belajar, dan minimnya balai pendidikan. maka beliau mendermakan diri untuk melakukan upaya pembinaan dan pengajaran terhadap masyarakat secara langsung.

Kehadiran KH. Ahmad Dahlan dan Muhammadiyahnya tepat pada waktunya. Sebab, keduanya datang di tengah masyarakat Islam yang sedang mengalami kemunduran dan kebekuan dalam berfikir. Terutama tentang kepercayaan masyarakat yang masih kuat berpegang kepada perkara-perkara tahayul, bid'ah, dan khurafat. (Abdul et al., 2014) Karenanya, sejak awal berbagai upaya dalam membangun kesadaran akan pentingnya pendidikan Islam modern mulai dirintis, pembaharuan paham dalam keislaman mulai disentuh, konsep kemajuan mulai disemai dalam alam pemikiran, peran perempuan yang masih termarginalkanpun mulai diperhatikan.

\section{Pendidikan Sebagai Embrio Muhammadiyah}

Berbicara tentang pendidikan di Indonesia tidak bisa lepas dari peran serta KH. Ahmad Dahlan melalui Muhammadiyahnya. Hal ini disebabkan karena Muhammadiyah telah berkiprah khususnya di bidang pendidikan sejak lahirnya (Mawardi, 2017). Meskipun Muhammadiyah tidak terlahir sebagai gerakan pendidikan, namun manifestasi gerakannya yang paling menonjol dan mengakar justru bidang pendidikan. Bidang pendidikan di muhammadiyah dibuktikan dengan banyaknya sekolah yang didirikan hampir setiap penjuru tanah air hingga di tingkat internasional (Susilo, 2016). Capaian ini jelas secara kuantitas sangat membanggakan (Nuryana, 2017), bahkan, gerakan pendidikan telah menjelma sebagai ruh dan nafas bagi Muhammadiyah. Hal ini tidak berlebihan, sebab secara historis terbukti bahwa KH. Ahmad Dahlan telah terlebih dahulu mendirikan Madrasah Ibtidaiyah Diniyah Islamiyah pada tanggal 1 Desember 1911 M. Artinya, Kyai Ahmad Dahlan mempunyai gagasan untuk membentuk lembaga pendidikan yang kemudian menumbuhkan organisasi Muhammadiyah sebagai media gerakan dakwah.(Abdul et al., 2014)

Secara historis dapat dikatakan bahwa sebenarrnya Muhammadiyah berasal dari "rahim pendidikan" dan terlair sebagai "gerakan pendidikan". Bermula dari sebuah balai pendidikan yang sederhana, Muhammadiyah diwacanakan dan dirumuskan hingga dideklarasikan sebagai sebuah ormas Islam. Maka, dalam perjalanannya Muhammadiyah tidak akan bisa keluar dari garis nasab yang melekat padanya sebagai "gerakan pendidikan". Ketika Muhammadiyah terbentuk pada tahun 1912, Pemikiran visioner-antisipatoris KH. Ahmad Dahlan seakan menemukan bumi berpijaknya. Organisasi ini memiliki grafik pertumbuhan yang signifikan. Sebagai gerakan islam, dakwah dan tajdid, Muhammadiyah memiliki ruang gerak yang tak terbatas pada bidang pendidikan saja. Apalagi sejak tahun 1917 Muhammadiyah melahirkan beberapa majelis yang membuatnya mempunyai 
wilayah kerja yang semakin luas. Tercatat ada empat majelis yang muncul diawal waktu yang saat itu dikenal dengan istilah bagian. Yaitu bagian sekolahan, bagian pustaka, bagian tabligh, dan bagian penolong kesengsaraan umum (PKU). Catatan sejarah ini sekaligus menjadi bukti bahwa Muhammadiyah sejak awal telah mengambil peran dalam dunia pendidikan. Hal ini ditempuh oleh karena Muhammadiyah memahami betul bahwa pendidikan dalam makna seluas-luasnya merupakan kunci kemajuan dan kegemilangan suatu bangsa (masyarakat, kaum, negara)(Ali, 2016).

\section{Pendidikan Integratif Holistik Bukan Dikotomis Parsial}

Penjajahan yang berjalan sedemikian lama bukan hanya mengakibatkan menculnya kesenjangan dalam strata sosial ekonomi, namun juga menyemai sistem dikotomis dan dualisme dalam pendidikan. Pendidikan kolonial melarang masuknya pelajaran agama dalam sekolah-sekolah kolonial.(Suaramuhammadiyah, 2017) Bukan sekedar menerapkan system dikotomis-dualistik, namun ekspansi sekolah Belanda diproyeksikan sebagai pola baru penjajahan yang dalam jangka panjang diharapkan dapat menggeser lembaga pendidikan Islam semacam pondok pesantren (Ni'mah, 2014). Disatu sisi pihak penjajah menyediakan balai pendidikan ala barat yang modern dan sekuler yang hanya fokus pada ilmuilmu umum. Sementara disisi yang lain, pribumi bertahan dengan pola pendidikan pesantren yang tradisional dan kolot yang hanya mengajarkan nilai-nilai keislaman. Kubu penjajah melarang hadirnya ilmu keislaman dalam balai pendidikan yang didirikannya, sementara umat Islam sebagai pribumi bersikap anti terhadap ilmu umum yang diyakini sebagai produk orang kafir.

Dualisme pendidikan yang ada memunculkan dua kelas sosial yang berbeda. Yang pertama menghasilkan masyarakat yang elitis dan yang kedua menghasilkan masyarakat yang memegang teguh tradisi dan budaya serta anti terhadap perubahan. Akhirnya, keberadaan ilmu keislaman dan ilmu umum seakan menjadi dua kutub yang berseberangan dan berlawanan yang tidak mungkin bertemu dan bersanding bersama dalam satu system pendidikan yang integral. Pemisahan ilmu dalam dunia pendidikan, telah mengantar dunia pendidikan di Indonesia menjadi suatu pendidikan yang mandul dan menghasilkan ilmuwan-ilmuwan yang tidak bertanggungjawab terhadap kehidupan kemasyarakatan dan lingkungan. Demikian pula pendidikan agama yang terlalu memisah dari dunia ilmu-ilmu sosial dan humaniora, telah melahirkan ahli-ahli agama yang tidak peka terhadap kehidupan sosial, dan gagap tehadap perkembangan dunia modern. (Bisryi, 2009) Padahal dalam prespektif Islam, ilmu sudah terkandung secara esensial dalam al Qur'an. Beragama berarti berilmu dan berilmu berarti beragama. Karena itu, tidak ada dikotomi antara ilmu dan agama.(Suyatno, 1970)

Berawal dari ketidakseimbangan antara pendidikan ilmu agama dan ilmu umum, lahirlah gagasan untuk melakukan pembaharuan. Sebab, dalam konsep pemikiran beliau, tidak boleh ada dikotomi dan dualisme antara ilmu Agama dan umum. Sebab, dalam dunia pendidikan pemisahan antara ilmu dan agama ini berakibat pada rendahnya mutu pendidikan dan kemunduran dunia Islam pada umumnya 
(Abdullah, 2003). Dihadapkan pada dualisme sistem pendidikan ini, KH.Ahmad Dahlan gelisah dan bekerja keras sekuat tenaga untuk mengintegrasikan, atau paling tidak mendekatkan kedua sistem pendidikan itu (Ni'mah, 2014). Bentuk tindak lanjut, muncullah gagasan dan upaya untuk mendirikan sekolah yang mengintegrsikan antara ilmu agama dan ilmu umum. Selanjutnya, menyadari akan sulitnya merealisasikan gagasan tersebut, maka sebagai langkah awal dibangunlah kerjasama dengan kolonial Belanda. Yaitu dengan ikut serta mengambil peran sebagai salah satu guru di sekolah yang dikelola Belanda. Inilah babak baru dalam sejarah Muhammadiyah sebagai langkah awal untuk merentas gerakan pendidikan yang integral.

Selanjutnya, secara mandiri KH. Ahmad Dahlan mendirikan Madrasah Ibtidaiyah Diniyah Islamiyah di Kauman Yogyakarta, dalam mengelola pendidikan ini, beliau memberikan sentuhan sistem klasikal barat. Yaitu melengkapi sekolah dengan berbagai fasilitas penunjang yang memadai seperti; bangku, kursi dan papan tulis.(Arofah \& Jamu’in, 2015) Kondisi ini sudah barang tentu menyimpang dari tradisi pendidikan pesantren yang identik dengan metode sorogan, bandongan atau wetonan. Dan, hanya karena menerapkan konsep yang tidak sesuai dengan kebanyakan inilah beliau dicela sebagai kyai kafir. Sebab, para kyai menilai beliau telah menabrak tradisi pesantren dan mengikuti pola pendidikan Belanda yang non Islam. Dalam konteks ini dapat dikatakan bahwa munculnya Madrasah Diniyah semacam ini merupakan ekspresi ketidakpuasan KH. Ahmad Dahlan terhadap sistem pendidikan pesantren yang telah ada.(Asran \& Wan Zakaria, 2015)

Pola pendidikan yang diterapkan oleh kolonial Belanda, sangat kontradiktif dengan pola pendidikan tradisional Islam yang ada. Namun, harus diakui bahwa sistem serta metode pendidikan dan pengajaran yang diimplementasikan dalam lembaga pendidikan mereka jauh lebih baik dan modern bila dibandingkan dengan sistem dan metode pada lembaga pendidikan tradisional Islam (Sabarudin, 2015). Karena itu, dengan mengadopsi sebagian system pendidikan yang ada disekolah kolonial, lalu mengkombinasikan dengan system pendidikan pesantren dan kearifan lokal, maka lahirlah balai-balai pendidikan yang menggabungkan disiplin ilmu umum dan disiplin ilmu Islam. Hal ini relevan dengan tujuan pendidikan Muhammadiyah yaitu menciptakan kader yang intelektual dan islami. Artinya, kader intelek yang menguasai pengetahuan secara umum dan kader islami yaitu menguasai ilmu keislaman. Atau dengan kata lain mencetak ulama intelektual dan intelektual ulama.(Supriyanto Muammar, 2011)

Zaman telah berganti, persoalan dikotomi merupakan masalah usang sudah tidak lagi relevan dengan dinamisasi kehidupan. Pendidikan Islam harus menuju pada integritas antara ilmu agama dan ilmu umum untuk tidak melahirkan jurang pemisah diantara keduanya. Karena, dalam prespektif Islam ilmu pengetahuan adalah satu yaitu yang berasal dari Allah (Tajab, 2014). Muhammadiyah sejak awal berdiri telah berkomitmen untuk terus berjuang mencerdaskan kehidupan bangsa melalui jalur pendidikan. Dalam pelaksanaannya, Muhammadiyah 
memadukan antara sistem pendidikan pesantren yang tradisional dengan sistem pendidikan sekolah yang modern, menjadi sistem pendidikan madrasah atau sekolah agama (Purba, 2013). Merujuk pada realitas tersebut, tidak mengherankan apabila Amal Usaha Muhammadiyah (AUM) di bidang pendidikan hingga saat ini terus berkembang pesat disemua jenjang baik secara kuantitas maupun kualitas. Pendidikan Muhammadiyah telah mampu menjadi perintis dan pelopor pendidikan Islam yang berwawasan kebangsaan dan kemanusiaan yang mampu menembus sekat-sekat sosial budaya. Mungkin saja, diantara sekian banyak rahasia dibalik kehebatan pendidikan Muhammadiyah adalah adanya sikap inklusifisme, ketulusan dalam pelayanan, dan tingginya dedikasi para tenaga pendidik dan pengelolanya dalam memajukan lembaganya. Termasuk sifat tekun, spirit kebersamaan dan kekompakannya dalam menghidupkan Amal Usaha Muhammadiyah (AUM), bukan mencari hidup di dalam Muhammadiyah, seperti pernah diwasiatkan oleh KH. Ahmad Dahlan.

\section{Pendidikan Tranformatif}

Dinamisasi cita-cita dalam melahirkan kehidupan berbangsa dan bernegera, berdampak masalah pendidikan sangat vital dan urgen untuk sebuah peradaban. Jadi, pendidikan harus dinamis dan transformatif dalam rangka menuju masa depan kehidupan manusia yang lebih baik.(Etika \& Para, 2017) Melalui konsep pendidikan transformatif setiap orang dituntut untuk bisa mengejawantahkan apa yang dipelajari sebagai wawasan dan keilmuan menjelma menjadi amalan dan perbuatan. Ilmu bukanlah materi yang tersimpan di kepala dalam bentuk teori dan rumus semata. Tapi, ilmu seharusnya berubah menjadi tindakan, andil, peran, pengabdian, sumbangsih kebaikan dan kemaslahatan untuk lingkungan sekitar.

Konsep pendidikan transformatif berawal dari kisah KH. Ahmad Dahlan yang mengajarkan surat al Maun kepada segenap santrinya. Metode pembelajaran yang dikembangkan beliau bercorak kontekstual melalui proses penyadaran (Arofah \& Jamu'in, 2015). Surat tersebut dipelajari berulangulang meskipun para santri telah menghafalkannya. Hingga saatnya tiba, beliau mempertanyakan kepada mereka apakah isi dan kandungan surat tersebut sudah diamalkan? Maka, keesokan harinya, dengan membawa berbagai barang yang dimiliki, KH. Ahmad Dahlan mengajak menyantuni orang-orang miskin dilingkungan sekitar.

Demikianlah, K.H. Ahmad Dahlan sejak awal telah mengembangkan konsep pendidikan yang berelevansi dengan lingkungan kehidupan. Konsep ini melahirkan prinsip ilmu amaliah, amal ilmiah. Jadi, ilmu akan bermanfaat ketika diamalkan untuk kepentingan masyarakat banyak (Ahmad, 2015). Pendidikan yang memiliki konsekuensi sosial inilah yang menjadi sumber kesadaran Muhammadiyah untuk membangun sikap peduli terhadap lingkungan sosial. Sebab, sikap peduli terhadap lingkungan sosial merupakan misi risalah Islam. Yaitu berupa upaya memobilisasi orang untuk melakukan tindakan positif konstruktif, mencegah orang dari perbuatan negatif destruktif, menghalalkan yang baik, mengharamkan yang buruk, mengatasi himpitan hidup, dan melepaskan belenggubelenggu yang bisa menghancurkan manusia. 
Makanya, siapapun yang tidak memiliki kepekaan dan kepedulian terhadap masalah social kemasyarakatan dicap sebagai pendusta agama.

Hakikat pendidikan adalah keseimbangan wawasan dan perbuatan, ketersambungan teori dan kenyataan, kesesuaian konsep dan praktek. Pendidikan transformatif menjadikan ilmu bukan sebatas wacana di dunia maya. Namun, mengubah ilmu sebagai prestasi nyata yang membumi dalam kehidupan sehari-hari. Dalam perkembangannya konsep yang demikian lebih dikenal dengan istilah teologi transformatif. Artinya, syariat islam bukanlah semata ajaran ritual vertical antara manusia dengan Tuhan, namun lebih daripada itu Islam hadir sebagai problem solver bagi permasalahan masyarakat. Konsep inilah yang juga dikenal sebagai teologi amal yang menjadi karakteristik Ahmad Dahlan dan awal kelahiran Muhammadiyah.(Arofah \& Jamu'in, 2015)

Tidak banyak naskah tertulis dan dokumen yang dapat dijadkan bahan untuk mengkaji dan merumuskan pemikiran dari Kyai Dahlan, hal ini disebabkan karena Kyai Dahlan memang bukan penulis. Kyai Dahlan mempunyai prinsip lebih “banyak bekerja dari pada berteori”.(Khadafi \& Supriyanto, 2011). Dengan spirit Al Maun, Muhammadiyah mewariskan gerakan pembebasan umat dari kebodohan, keterbelakangan dan ketidakberdayaan. Sebab, Islam menegaskan bahwa misi dari setiap ritus Islam adalah akuntabilitas sosial, tanpa implikasi sosial, semua ritus Islam yang dilakukan dipandang sebagai kesia-siaan belaka.(Hemlan Elhany, 2013). Berawal dari konsep pendidikan transformatif, Muhammadiyah melahirkan trisula pemberdayaan masyarakat. Sula pertama; gerakan pendidikan dengan mendirikan balai pendidikan diseluruh jenjang yang tersebar diseluruh penjuru Indonesia dan telah mulai merambah keluar negeri. Sual kedua; gerakan kesehatan dengan mendirikan berbagai balai kesehatan dan yang terbaru Muhammadiyah Disaster Manajemen Center (MDMC). Sula ketiga; gerakan ekonomi dengan membentuk lazismu dan lembaga mikro keuangan Baitut Tamwil Muhammadiyah (BTM) dan juga koperasi.

\section{Fungsi dan Tujuan Pendidikan \\ Muhammadiyah}

Ada empat perspektif atau pandangan berkiatan dengan fungsi pendidikan Muhammadiyah. Adapun empat fungsi tersebut antara lain: pertama, sebagai sarana pendidikan dan pencerdasan; kedua, sebagai pelayanan msayarakat; ketiga, sebagai gerkan dakwah amar ma'ruf nahi mungkar; dan keempat, sebagai area kaderisasi (Nuryana, 2017). Fungsi pendidikan Muhammadiyah tersebut sekaligus menjadi solusi dan respon terhadap keringnya ruh keagamaan dalam pendidikan. Seluruh Amal Usaha Muhammadiyah (AUM) dalam bidang pendidikan harus melaksanakan pendidikan al Islam dan Kemuhammadiyahan sebagai fondasi pendidikan. Kebijakan ini semakin mempertegas posisi Muhammadiyah sebagai gerakan pendidikan.

Terkait tujuan sebuah pendidikan, tentunya hal itu akan berbanding lurus dengan konsep perubahan yang diharapkan terjadi pada peserta didik baik secara personality maupun sosiality. Tujuan utama sebuah pendidikan seharusnya seirama dan senafas dengan pandangan hidup bangsa yang bersangkutan. Karenanya, tidak mengherankan manakala tiap Negara dan bangsa 
memiliki tujuan pendidikan yang berbeda-beda. Semua itu terjadi karena pendidikan diarahkan untuk membentuk pola kehidupan sesuai arah kebijakan bangsa dan negara yang bersangkutan. Berpijak dari paradigma inilah Muhammadiyah sebagai bagian dari bangsa dan Negara Kesatuan Republik Indonesia merumuskan tujuan pendidikan yang hendak diwujudkan. Secara historis, tujuan pendidikan Muhammadiyah dirumuskan pertama kali pada tahun 1936, yaitu 13 tahun setelah pendiri Muhammadiyah meninggal dunia(Ali, 2016).

Dinamika tujuan pendidikan Muhammadiyah bisa dikategorikan menjadi dua fase, yaitu fase pra-perumusan dan fase perumusan.

\section{a. Fase pra-perumusan}

Tujuan pendidikan Muhammadiyah belum dirumuskan secara eksplisit sebagai sebuah formalitas dan legalitas. Sebab, tujuan itu secara otomatis menyatu dalam setiap diam dan gerak KH. Ahmad Dahlan sebagai pendiri Muhammadiyah. Maka, semua perkataan dan perbuatan beliau dalam mengelola organisasi ini bisa disebut sebagai bentuk pedoman, panduan dan haluan bagi perjalanan pendidikan Muhammadiyah itu sendiri. Maka, ketika KH. Ahmad Dahlan berkata:

"dadiyo kyai sing kemajuan, lan aja kesel-kesel anggonmu nyambut gawe kanggo Muhammadiyah. Artinya, jadilah ulama yang berkemajuan, dan tidak kenal lelah bekerja dan beramal untuk Muhammadiyah".

Maka, inilah arah dan tujuan pendidikan Muhammadiyah yang bertujuan untuk terbentuknya pribadi ulama intelektual intelektual ulama yang berorientasi pada pelayanan umat. Pendidikan Muhammadiyah diarahkan untuk mencetak pribadi Muslim yang mapan dalam penguasaan ilmu keislaman dan cakap dalam ilmu keduniaan serta siap mendedikasikan diri tanpa lelah demi kebaikan dan kemaslahatan bangsa dan Negara.

Tentang tujuan hadirnya Muhammadiyah sendiri pada era awal telah dirumuskan pada tahun 1914 sebagai berikut:

"Hendak menyebarkan pengajaran agama Islam kepada penduduk bumi putera di dalam residensi Jogjakarta dan hendak memajukan agama Islam kepada anggota-anggotanya”

Rumusan ini telah mencantumkan kata "memajukan" sebagai bukti akan inklusifisme dan misi modernitas dalam tubuh Muhammadiyah. Mengingat pada zaman itu bangsa masih terbungkus oleh keterbelakangan.

\section{b. Fase perumusan;}

Fase ini tampak terjadi modifikasi pada teks perumusan secara formal. Hal itu terlihat pada perubahan perumusan dari masa ke masa. Berikut secara rinci perubahan rumusan tersebut:

1. Permusan Jakarta 1921 berbunyi: "1. Memajukan dan menggembirakan pengajaran dan pelajaran agama Islam di Hindia Nederland; 2. Memajukan dan menggembirakan cara kehidupan sepanjang kemauan agama Islam kepada Lid-lidnya (segala sekutunya)".

2. Perumusan tahun 1936 yang berbunyi: "1. Menggiring anak-anak Indonesia menjadi orang Islam yang berkobar semangatnya dengan khusyuknya, pekertinya halus lagi cerdas otaknya. 2. Badannya sehat, tegap bekerja. 3. Hidup tangannya mencari rezeki sehingga kesemuanya itu memberi 
faedah yang besar dan berharga tinggi bagi dirinya dan juga bagi masyarakat hidup bersama”.

3. Perumusan tahun 1954 yang berbunyi: "Membentuk manusia Muslim berakblak mulia, cakap, percaya pada diri sendiri dan berguna pada masyarakat"

4. Perumusan tahun 1971 yang berbunyi: "Terwujudnya manusia Muslim berakblak mulia, cakap, percaya kepada diri sendiri dan berguna bagi masyarakat dan Negara”. Kemudian rumusan ini disempurnakan menjadi : "Termujudnya manusia Muslim yang bertaqwa, berakblak mulia, percaya kepada diri sendiri, cinta tanah air dan berguna bagi masyarakat dan Negara, beramal menuju terwujudnya masyarakat utama, adil dan makmur yang diridhai Allab SWT'”.

Mencermati paparan diatas dapat disimpulkan bahwa Muhammadiyah sejak lahirnya telah concern dalam bidang pendidikan. Dan yang menarik adalah betapa gerakan pendidikan Muhammadiyah memiliki misi dan visi jauh kedepan dan berorientasi pada kebangsaan. Hal ini terlihat dari keselarasan tujuan pendidikan Muhammadiyah dengan tujuan pendidikan nasional.

\section{KESIMPULAN}

Muhammadiyah hadir sebagai gerakan pendidikan yang telah mewarnai perjalanan pendidikan nasional. Berawal dari keprihatinan terhadap keterpurukan bangsa dalam semua aspek kehidupan, KH. Ahmad Dahlan terpanggil untuk berkiprah membenahi kondisi yang sedang dihadapi dengan mengambil peran dalam sektor pendidikan. Bermula dari sebuah balai pendidikan yang sederhana, beliau memperkenalkan konsep modernitas. Seiring berjalannya waktu, lahirlah Muhammadiyah yang mengusung slogan berkemajuan. Konsentrasi beliau menggarap dunia pendidikan tidak lepas dari pemikirannya yang menilai bahwa kemajuan suatu bangsa berawal dari pendidikan. Maka, tidak berlebihan mankala pemerintah memberikan apresiasi kepada beliau atas jasa-jasanya dan menjadikannya sebagai salah satu pahlawan nasioanal.

\section{DAFTAR RUJUKAN}

Abdullah, Amin, dkk. (2003). Menyatukan Kembali Ilmu-Ilmu Agama dan Umum: Upaya mempertemukan Epistemologi Islam. Yogyakarta: SUKA Press.

Abdul, M., Binfas, M., \& Ismail, A. M. (2014). Tapak Perbezaan Asal Usul Gerakan Muhammadiyah Dan Nahdlatul Ulama (Nu) Di Indonesia the Chronicled Distinction Between Muhammadiyah and Nahdlatul Ulama Movements in Indonesia. Jurnal Melayu Jilid.

Ahmad, F. (2015). Pemikiran K.H. Ahmad Dahlan tentang Pendidikan dan Implementasinya di SMP Muhammadiyah 6 Yogyakarta Tahun 2014/2015. Profetika Jurnal Studi Islam.

Ali, M. (2016). Membedah Tujuan Pendidikan Muhammadiyah. Profetika, Jurnal Studi Islam.

Arofah, S., \& Jamu'in, M. (2015). Gagasan Dasar dan Pemikiran Pendidikan Pendidikan Islam K.H Ahmad Dahlan. Tajdida.

Asran, M. A., \& Wan Zakaria, W. F. A. (2015). Reformasi Pendidikan al-Hadi dan alFaruqi. Islamiyyat. https://doi.org/10.17576/islamiyyat-20153701-04

Bisryi, H. (2009). Mengakhiri Dikotomi Ilmu 
Dalam Dunia Pendidikan. Jurnal Forum Tarbiyah.

Etika, R., \& Para, B. (2017). PENDIDIKAN TRANSFORMATIF : Islamuna.

Hemlan Elhany. (2013). Perspektif KH. Ahmad Dahlan Tentang Pengembangan Masyarakat Islam. PERSPEKTIF KH. AHMAD DAHLAN TENTANG PENGEMBANGAN MASYARAKAT ISLAM.

Khadafi, M., \& Supriyanto, A. (2011). Studi Analisis Pemikiran K. H . Ahmad Dahlan tentang Pendidikan Islam di Indonesia. Turats.

Mafidin. (2012). STUDI LITERATUR TENTANG PERAN MUHAMMADIYAH DALAM MENGEMBANGKAN PENDIDIKAN ISLAM DI INDONESIA. Jurnal Tarbawi.

Ni'mah, Z. A. (2014). Pemikiran Pendidikan Islam Perspektif KH AHMAD DAHLAN 1869-1923 M ) DAN KH HASYIM AS'ARI (1871-1947) Study Komparatif dalam Konsep Pembaruan Pendidikan Islam di Indonesia. Didaktika Religia.

Nuryana, Z. (2017). Revitalisasi Pendidikan AlIslam Dan Kemuhammadiyahan Pada Perguruan Muhammadiyah. Jurnal Tamaddun.

Purba, I. A. (2013). Perkembangan Amal Usaha Organisasi Muhammadiyah di Bidang Pendidikan dan Kesehatan. Jurnal Ilmu Pemerintahan Dan Sosial Politik UMA.

Sabarudin, M. (2015). Pola dan Kebijakan Pendidikan Islam Masa Awal dan Sebelum Kemerdekaan. Jurnal Tarbiya UIN SGD.

Suaramuhammadiyah. (2017). Sejarah Singkat Muhammadiyah | Pimpinan Pusat Muhammadiyah.

Supriyanto Muammar, A. K. (2011). Studi Analisis Pemikiran K.H. Ahmad Dahlan tentang Pendidikan Islam di Indonesia. Jurnal FAI : TURATS.

Susilo, M. J. (2016). Kajian kemandirian sekolah di amal usaha muhammadiyah. In Prosiding Seminar Nasional Pendidikan Berkemanjuan dan Menggembirakan.

Suyatno, S. (1970). Dekonstruksi pendidikan Islam sebagai subsistem pendidikan nasional. Jurnal Pendidikan Islam.

https://doi.org/10.14421/jpi.2012.11.121138

Tajab, M. (2014). SINTESA ATAS DIKOTOMI PENDIDIKAN ISLAM. At-Tajdid: Jurnal Ilmu Tarbiyah. 